\title{
Erratum to: Modeling population dynamics and conservation of arapaima in the Amazon
}

\author{
L. Castello • D. J. Stewart • C. C. Arantes
}

Published online: 4 November 2011

(C) Springer Science+Business Media B.V. 2011

\section{Erratum to: Rev Fish Biol Fisheries (2011) 21:623-640 \\ DOI 10.1007/s11160-010-9197-z}

The original article is published with incorrect values in the first paragraph below the subtitle "Basin-wide production." The correct version of the text is given below for your reading.

The online version of the original article can be found under doi:10.1007/s11160-010-9197-z.

\section{Castello · C. C. Arantes}

Mamirauá Institute for Sustainable Development,

Tefé, Amazonas, Brazil

L. Castello · D. J. Stewart

Department of Environmental and Forest Biology,

College of Environmental Science and Forestry, State

University of New York, Syracuse, NY 13210, USA

L. Castello $(\square)$

The Woods Hole Research Center, Falmouth,

MA 02540, USA

e-mail: 1castello@whrc.org

C. C. Arantes

Departamento de Ciências Exatas e Tecnológicas,

Universidade Estadual de Santa Cruz, Ilhéus, Bahia,

Brazil

C. C. Arantes

Instituto de Pesquisa Ambiental da Amazônia,

Santarém, Brazil
"On a per hectare basis, these values are $0.33,0.31$, and 0.04 indiv. $\mathrm{ha}^{-1}$, respectively, and they offer a comparative baseline to assess the health of arapaima populations elsewhere (e.g., community-based management)." 